\title{
Implementasi Peraturan Daerah Kota Pontianak Nomor 16 Tahun 2015 Tentang Retribusi Jasa Umum Pada Retribusi Pelayanan Pasar Flamboyan Kota Pontianak
}

\author{
Ahadian Gunardi ${ }^{1}$ \\ 1. Kementrian Agama RI Kota Pontianak \\ Korespondensi Penulis : ahadiangunardi@yahoo.com
}

\begin{abstract}
The aim of this study is to describe and analyze the implementation of the regional regulation of Pontianak Number 16 the year 2015 concerning Public Service Retribution on Service Charges in the Flamboyan Market in Pontianak. There are 2 (two) indicators based on the research problems that influence the success of policy implementation performance are the characteristics of implementing agencies and communication between organizations and implementing activities. The method used in this research is descriptive qualitative. The results of this study indicate that the attitude of assertiveness by retribution officers is still low in responding to complaints of traders. The officers who collect the retribution are not continual in providing information through socialization about the importance of retribution paying to transparent traders and the availability of inadequate information facilities. The suggestion in this research is that it is necessary to coordinate among policy implementer to provide fast, precise and responsive services to complaints from traders in the Flamboyan market. Besides, providing counseling and guidance by providing transparent and new information to traders through adequate information facility.
\end{abstract}

Keywords : Policy Implementation, Public Services Retribution. 


\section{PENDAHULUAN}

Pembangunan

ekonomi

Indonesia terus dilakukan meliputi segala aspek kehidupan. Tujuannya adalah untuk menciptakan masyarakat yang sejahtera, adil dan makmur. Dalam upaya mencapai masyarakat yang adil dan makmur, pembangunan ekonomi perlu ditingkatkan melalui perbaikan pendapatan serta peningkatan daya beli masyarakat. Dalam rangka perbaikan pendapatan dan peningkatan daya beli masyarakat diperlukan peningkatan retribusi daerah yang merupakan kewajiban yang harus dipenuhi kepada negara yang bertujuan untuk kesejahteraan masyarakat di Indonesia.

Retribusi pelayanan pasar dipungut oleh pemerintah Kota Pontianak dan berlandaskan hukum, yaitu dalam Peraturan Daerah Kota Pontianak Nomor 16 Tahun 2015 Tentang Retribusi Jasa Umum Pada Retribusi Pelayanan Pasarsebagai dasar atau pedoman bagi penerimaan retribusi pasar yang berkenaan dengan kontribusi pendapatan asli daerah (PAD) Kota Pontianak sebagai salah satu daerah otonom. Tujuan kebijakan Perda Nomor 16 Tahun 2015 adalah untuk meningkatkan pendapatan asli daerah (PAD) Kota Pontianak, hal ini tercantum dalam konsideran Peraturan Daerah Kota Pontianak Nomor 16 Tahun 2015 Tentang Perubahan Kedua Atas Peraturan Daerah Nomor 4 Tahun 2011 Tentang Retribusi Jasa Umummengenai perubahan besarnya tarif retribusi pasar yang baru sesuai dengan pasal 43 sampai dengan pasal 44 dari peraturan tersebut. Retribusi pelayanan pasar dapat memberikan manfaat baik untuk pedagang pasar maupun untuk pemerintah Kota Pontianak.

Manfaat retribusi pasar bagi pedagang antara lain meningkatkan pelayanan dalam hal penyediaan, penggunaan dan perawatan pasar yang berupa halaman atau pelataran, kios dan los yang dikelola oleh pemerintah. Sedangkan manfaat retribusi pasar bagi pemerintah Kota Pontianak sebagai salah satu sumber pemasukan retribusi daerah yang potensial untuk meningkatkan pendapatan asli daerah (PAD) Kota Pontianak. Hal ini termasuk pula retribusi pelayanan pasar di pasar Flamboyan Kota Pontianak.

Pasar Flamboyan merupakan 
salah satu pasar tradisional yang ada di Kota Pontianak, salah satu pusat kegiatan jual beli bagi masyarakat Kota Pontianak mulai dari masyarakat menengah ke bawah sampai masyarakat menengah ke atas. Pasar Flamboyan secara administratif berada dibawah Dinas Koperasi Usaha Mikro Dan Perdagangan Kota Pontianak melalui Unit Pelaksana Teknis (UPT) Pasar Flamboyan. Unit Pelaksana Teknis (UPT) Pasar Flamboyan merupakan suatu unit kerja yang bertujuan untuk memberikan pendapatanbagi daerah Kota Pontianak melalui pemungutan retribusi pasar yang dilakukan oleh petugas pemungut retribusi terhadap pedagang yang menempati kios dan los yang ada di pasar Flamboyan. Untuk memaksimalkan penerimaan retribusi pasar ini, maka pemerintah Kota Pontianak perlu memanfaatkan potensi yang ada di pasar Flamboyan agar bisa dimanfaatkan para pedagang untuk berjualan sehingga retribusi pun meningkat. Potensi yang ada tersebut berupa penetapan tarif retribusi jasa umum pada retribusi pelayanan pasar tradisional di Kota Pontianak.

Besaran tarif retribusi pelayanan pasar sesuai dengan Peraturan Daerah Kota Pontianak Nomor 16 Tahun 2015 ditentukan berdasarkan ukuran luas tempat yang digunakan, yaitu untuk kios dengan ukuran 2x3 $\mathrm{M}^{2}$ sebesar Rp. 3.000,- per hari sedangkan untuk los dengan ukuran 1x1,5 $\mathrm{M}^{2}$ sebesar Rp. 2.000,- per hari. Tarif retribusi pasar yang telah ditetapkan oleh pemerintah Kota Pontianak bertujuan untuk mencapai target penerimaan retribusi pasar yang cukup besar bagi peningkatan pendapatan asli daerah (PAD) Kota Pontianak, khususnya pada pasar Flamboyan.

Pengenaan tarif retribusi pasar terhadap pedagang pasar Flamboyan bertujuan untuk memperbaiki sarana dan prasarana fasilitas pasar yang digunakan oleh pedagang selama ini sesuai dengan peruntukannya. Namun, dalam pelaksanaannya terdapat kendala/ permasalahan di lapangan berdasarkan hasil observasi awal oleh peneliti tanggal 27 Januari 2020, yakni masih adanya kondisi sarana fasilitas pasar yang rusak, yakni adanya kebocoran disalah satu atap los pasar Flamboyan menyebabkan becek yang sangat mengganggu aktivitas pedagang berjualan sehingga perlu penanganan 
cepat oleh Dinas Koperasi Usaha Mikro Dan Perdagangan Kota Pontianak dan kurangnya kesadaran dan kepatuhan pedagang untuk membayar retribusi tepat waktu, sehingga pedagang enggan untuk membayar retribusi pasar, hal ini dapat menyebabkan target penerimaan retribusi pasar Flamboyan tidak mencapai $100 \%$ setiap tahunnya sebagai kontribusi pendapatan asli daerah (PAD) Kota Pontianak.

Target penerimaan retribusi pasar yang diperoleh dari kios/los pada pasar Flamboyan dihitung berdasarkan jumlah kios/los yang ditempati pedagang yang aktif menjual dagangannya dikalikan dengan besaran tarif retribusi yang dikenakan setiap harinya. Namun demikian, masih adanya perbedaan dalam penentuan target penerimaan retribusi yang ditetapkan oleh pemerintah Kota Pontianak yang terlalu tinggi dibandingkan jumlah hitungan target penerimaan retribusi pasar yang sebenarnya, yakni Rp. 1.780.000,target penerimaan retribusi pasar setiap hari, sedangkan Rp. 640.800.000,target penerimaan retribusi pasar setiap tahunnya. Hal ini dikarenak pemerintah Kota Pontianak melalui Dinas Koperasi Usaha Mikro Dan Perdagangan Kota Pontianak sudah menentukan targetnya sesuai dengan kondisi pasar dan kemampuan pedagang pasar Flamboyan, akan tetapi pihak DPRD Kota Pontianak memilik target penerimaan retribusi pasar dengan hitungan sendiri sesuai dengan aturan yang dibuat oleh DPRD Kota Pontianak sehingga target yang ditentukan sangat tinggi.

Adanya kenaikan dan penurunan target penerimaan retribusi pasar Flamboyan setiap tahunnya disebabkan oleh kondisi ekonomi Kota Pontianak, khususnya pasar Flamboyan yang didasarkan pada potensi kemampuan pedagang dalam membayar retribusi pelayanan pasar berdasarkan kios/los yang ditempati pedagang atas usulan dari Dinas Koperasi Usaha Mikro Dan Perdagangan Kota Pontianak yang disampaikan kepada DPRD Kota Pontianak untuk dikaji, dianalisa, dan ditetapkan atas kesepakatan bersama berupa penetapan target penerimaan retribusi pelayanan pasar setiap tahunnya. Berdasarkan latar belakang asalah yang penulis uraikan diatas, 
maka penulis tertarik untuk melakukan penelitian yang berjudul: "Implementasi Peraturan Daerah Kota Pontianak Nomor 16 Tahun 2015 Tentang Retribusi Jasa Umum Pada Retribusi Pelayanan Pasar Flamboyan Kota Pontianak."

Dari latar belakang yang telah dijelaskan diatas, maka peneliti melakukan identifikasi masalah antara lain:

1. Masih adanya kondisi sarana fasilitas pasar yang rusak, sehingga diperlukan penanganan yang cepat dari pemerintah Kota Pontianak.

2. Kurangnya kesadaran dan kepatuhan pedagang untuk membayar retribusi tepat waktu.

\section{METODE PENELITIAN}

Metode penelitian ini yang digunakan adalah analisis kualitatif melalui pendekatan deskriptif dengan menggunakan model implementasi kebijakan menurut Van Meter dan Van Horn, dimana prosedur pemecahan masalahnya diselidiki dengan menggambarkan atau melukiskan keadaan subjek atau objek penelitian (seseorang, lembaga masyarakat dan lain-lain) pada saat sekarang berdasarkan fakta-fakta yang tampak atau sebagaimana adanya yang meliputi interpretasi data dan analisis data. Moleong (2007:6) menyatakan penelitian kualitatif adalah penelitian yang bermaksud untuk memahami fenomena tentang apa yang dialami oleh subjek penelitian misalnya perilaku, persepsi, motivasi, tindakan, dan lain-lain, secara holistik, dan dengan cara deskripsi dalam bentuk kata-kata dan bahasa, pada suatu konteks khusus yang alamiah dan dengan memanfaatkan berbagai metode alamiah. Menurut Bogdan dan Taylor (1975:5) dalam Tohirin (2012:2) yang mendefinisikan metodologi kualitatif sebagai prosedur penelitian yang menghasilkan data deskriptif berupa kata-kata tertulis atau lisan dari orang-orang dalam perilaku yang dapat diamati.

Penetapan lokasi penelitian sangat penting dalam rangka mempertanggungjawabkan data yang diperoleh. Untuk itu peneliti memilihlokasi di pasar Flamboyan kota Pontianak beranggapan bahwa masih ada permasalahan dalam implementasi Peraturan Daerah Kota 
Pontianak Nomor 16 Tahun 2015. Penelitian ini dilaksanakan di UPT Pasar Flamboyan pada Dinas Koperasi Usaha Mikro dan Perdagangan Kota Pontianak. Subjek Penelitian

Teknik sampling non probabilitas yang digunakan oleh peneliti dalam menentukan subjek penelitian ini adalah metode snowball sampling yang menurut pendapat Sugiyono (2012:54) adalah teknik pengambilan sampel sumber data, yang pada awalnya jumlahnya sedikit, lama-lama menjadi besar. Hal ini dilakukan karena dari jumlah sumber data yang sedikit itu tersebut belum mampu memberikan data yang memuaskan, maka mencari orang lain lagi yang dapat digunakan sebagai sumber data. Dalam penelitian ini sumber data yang dipergunakan meliputi:

a. Data primer, yaitu data yang diperoleh langsung dari informan atau dari sumbernya berupa wawancara, sekaligus sebagai subjek penelitian.

b. Data sekunder, yaitu data yang diperoleh dengan cara menyalin atau mengutip catatan-catatan atau dokumen yang ada, sekaligus sebagai objek dari penelitian ini

Sedangkan yang menjadi objek penelitian adalah Implementasi Peraturan Daerah Kota Pontianak Nomor 16 Tahun 2015 Tentang Retribusi Jasa Umum pada Retribusi Pelayanan Pasar Flamboyan Kota Pontianak, yang termasuk ke dalam data sekunder pada penelitian ini.

\section{HASIL DAN PEMBAHASAN}

Berkenaan dengan implementasi kebijakan pemungutan retribusi pelayanan pasar Flamboyan di Kota Pontianak, maka dalam penelitian ini akan digunakan model implementasi kebijakan menurut Van Meter dan Van Horn (1975) dalam Agustino (2017:133-135) Dasar- dasar Kebijakan Publik yang mempunyai 6 (enam) indikator yang mempengaruhi kinerja implementasi kebijakan publik yang didasarkan oleh ukuran dan tujuan kebijakan, sumber daya, karakteristik agen pelaksana, sikap para pelaksana, komunikasi antar organisasi dan aktivitas pelaksana terkait dengan kegiatan-kegiatan pelaksanaan serta lingkungan sosial, ekonomi dan politik. 
Dari 6 (enam) indikator tersebut, peneliti hanya menganalisa dan membahas 2 (dua) indikator yang dapat mempengaruhi implementasi kebijakan retribusi jasa pelayanan pasar pada pasar Flamboyan Kota Pontianak, yakni karakteristik agen pelaksana dan komunikasi antarorganisasi serta aktivitas pelaksana sesuai dengan fokus permasalahan dalam penelitian ini, dapat dijelaskan sebagai berikut:

\section{Karakteristik Agen Pelaksana \\ Dalam Implementasi Kebijakan Retribusi Jasa Pelayanan Pasar}

Salah satu pendukung keberhasilan kinerja implementasi Peraturan Daerah Nomor 16 tahun 2015 tentang Retribusi Jasa Umum pada Retribusi Pelayanan Pasar pada pasar Flamboyan adalah karakteristik agen pelaksana. Fokus perhatian pada agen pelaksana meliputi organisasi formal dan organisasi informal yang akan terlibat dalam pengimplementasian kebijakan publik. Hal ini sangat penting karena kinerja implementasi kebijakan publik akan sangat banyak dipengaruhi oleh ciriciri yang tepat serta cocok dengan para agen pelaksananya. Hal ini termasuk bagaimana sikap para pelaksana dalam melaksanakan kebijakan Perda dan pengawasan terhadap pelaksanaan Perda dalam mendukung keberhasilan kinerja implementasi kebijakan.

Implementasi Peraturan Daerah Nomor 16 Tahun 2015 tentang Retribusi Jasa Umum Pada Retribusi Pelayanan Pasar pada pasar Flamboyan dapat mencapai target penerimaan $100 \%$, apabila petugas pemungut retribusi pasar memberikan sanksi yang tegas terhadap pedagang yang menunggak pembayaran retribusi, hal ini belum sejalan dengan apa yang disampaikan Kepala Bidang (Kabid) Pasar Dinas Koperasi, Usaha Mikro dan Perdagangan Kota Pontianak Bapak Rachmad Suprayetno, SH,MH. menuturkan, sebagai berikut:

"Untuk pedagang yang menunggak atau yang tidak bayar tentu kita ada sanksi, baik sanksi administrasi atau sanksi pidananya, kalau administrasi kita lakukan dengan cara memanggil yang bersangkutan kita memintai keterangan menanyakan masalahnya kenapa tidak bayar, kita siapkan pernyataan terus kalau tidak bayar, kita berikan teguran-teguran, bahkan kemudian izinnya pun kita tunda untuk perpanjangannya." Dan sedangkan dalam pencapaian target, kendala pasti ada lah, soalnya yang namanya masyarakat banyak pasti 
masalah pada pedagang ada berperilaku yang aktif dan tidak aktif, aktif alhamdulillah, yang tidak aktif khan tadi ada yang mungkin susah membayarnya, ada yang membayarnya tersendatsendat, terus bahkan menghindarmenghindar, jadi tetap ada lah kendala nya." (Wawancara Tanggal 07 April 2020)

Hal serupa disampaikan Kepala

Seksi Retribusi dan Registrasi

Pengelolaan Pasar Tradisional Dinas

Koperasi Usaha Mikro dan

Perdagangan Kota Pontianak Bapak

Harjuniardi, SE,ME menuturkan, sebagai berikut:

"Perilaku dari pedagang yang tidak mau membayarkan retribusi juga kita sifatnya tidak memaksakan yaa... karena kita belum melaksanakan eksekusi lah, kita mau melakukan tapi sekarang kita beri mereka untuk berjualan karena itu urusan perut yaa... kita sifatnya tidak memaksakan, kalau kita tegas eksekusi mungkin bisa, tapi pesan dari bapak walikota yaa... utamakan persuasif dulu, itu yang masih kita pegang karena terus terang yang berjualan berjualan dipasar flamboyan adalah masyarakat golongan menengah ke bawah, menengah ke bawah ini khan sumber kehidupan itu tidak ada, kalau menengah ke atas mungkin ada hal lain lah, ini menengah kebawah, jadi lebih kearah bagaimana membuat masyrakat itu lebih berusaha itu aja."(Wawancara Tanggal 06 April 2020)
Terkait dengan keluhan pedagang pasar Flamboyan, petugas pemungut retribusi pasar Bapak Feri

Keriwani menuturkan, sebagai berikut:

"Sebenarnya keluhan itu tiap pasar ada, cuman yaa... tergantung kitanya yang kedua kadang-kadang tindakan atau respon dari kantor itu lambat, misalnya pembangunan masih dibilang baru, ndak gak terlalu baru yaa... ada beberapa blok itu dia punya sudah bocor atapnya, kita lapor kadang-kadang di kantor kadang-kadang tindakannya lama, ini dilaporkan kha tadak nih... nagih jalan terus tidak dilaporkan, nah.. khan jadi kita nih maunya selaku penagih nih maunya cepat respon dari kantor itu, masalah di laksanakan atau tidaknya khan, itu khan tergantung dari anggaran, tapi jelasnya orang kantor itu turun dulu, liat, di foto atau gimana, tunjukkan bahwa kita ini sudah lapor dan orang kantor sudah respon jadi pedagang tidak banyak komen, kalau dia tidak ada respon, pedagang selalu komen, nagih jalan terus nih... tapi tak ada respon nih..., lapor kha tadak.., seperti itu, kadang kalau dia (pedagang) keadaan momen seperti itu susah kita nagih ke pedagang, kita pun orang (pedagang) dalam keadaan itu, kita hindarlah."(Wawancara Tanggal 07 April 2020).

Hal senada apa yang dikatakan penagih retribusi pasar Flamboyan Ibu Salbiah menuturkan, sebagai berikut:

"Kita tanggapi, Kita kalau
seandainya benar-benar tidak 
mampu, nah... kita berikan kelonggaran, bayarnya bulan depan atau bayarnya setiap hari, jadi kalau dia tidak bayar sekali, sanksinya ada di pembuatan suratnya." (Wawancara Tanggal 21 April 2020).

Dari hasil wawancara dan observasi yang dilakukan oleh peneliti terhadap informan diatas dapat diambil kesimpulan bahwa karakteristik agen pelaksana dalam keberhasilan kinerja implementasi Peraturan Daerah Kota Pontianak Nomor 16 Tahun 2015 Tentang Retribusi Jasa Umum Pada Retribusi Pelayanan Pasar menyangkut tentang bagaimana sikap petugas pemungut retribusi pasar dalam melaksanakan kebijakan Perda dan pengawasan terhadap pelaksanaan Perda dalam mendukung keberhasilan kinerja implementasi kebijakan.

Penetapan besaran tarif retribusi sesuai dengan Peraturan Daerah Kota Pontianak Nomor 16 Tahun 2015 tidak memberatkan pedagang berdasarkan ukuran tempat los/kios yang mereka gunakan dalam berjualan, yaitu untuk kios dengan ukuran 2x3 $\mathrm{M}^{2}$ sebesar Rp. 3.000,- per hari sedangkan untuk los dengan ukuran $1 \times 1,5 \mathrm{M}^{2}$ sebesar Rp. 2.000,- per hari. Tarif retribusi pasar yang telah ditetapkan oleh pemerintah Kota Pontianak bertujuan untuk mencapai target penerimaan retribusi pasar yang cukup besar bagi peningkatan pendapatan asli daerah (PAD) Kota Pontianak, khususnya pada pasar Flamboyan. Namun, masih ada beberapa pedagang yang membayar retribusi pasar seminggu sekali, sebulan sekali bahkan ada yang setahun sekali, hal ini disebabkan oleh sikap petugas pemungut retribusiyang belum tegas memberikan batas waktu pembayaran retribusi pasar ke pedagang, sehingga pedagang dalam membayar retribusi pasar tidak tepat pada waktunya.

Keterlambatan pembayaran retribusi oleh pedagang pasar Flamboyan, disebabkan petugas pemungut retribusi selalu memberikan kelonggaran waktu ke pedagang, yang sifatnya tidak memaksakan pedagang apabila tidak membayar pada hari itu tetapi bisa dibayarkan ke hari berikutnya, hal ini bertolak belakang dari aturan yang seharusnya pembayaran retribusi dilakukan setiap harinya oleh pedagang, sehingga kurangnya pengawasan yang dilakukan oleh Kasi Retribusi dan Registrasi Pengelolaan Pasar 
Tradisional terhadap kinerja petugas pemungut retribusi dalam pemungutan retribusi kepada pedagang, yang mengakibatkan penerimaan retribusi tidak maksimal, hal ini dapat mempengaruhi target penerimaan retribusi pasar Flamboyan.

Pengawasan dari pihak Dinas Koperasi Usaha Mikro Dan Perdagangan Kota Pontianak yang tidak rutin dilaksanakan setiap harinya tetapi dilaksanakan setiap 2 (dua) minggu sekali. Pengawasan yang dilakukan oleh Dinas Koperasi Usaha Mikro Dan Perdagangan Kota Pontianak terhadap petugas pemungut retribusi dan pedagang pasar Flamboyan, dengan cara:

1. Melihat sistem administrasi bukti hasil penagihan retribusipasar dan mengevaluasi setiap minggunya.

2. Melihat tertibnya administrasi pembukuan penagihan retribusi dan mengevaluasi kinerja petugas penaguh retribusi dalam melaksanakan pemungutan retribusi pasar.

3. Melakukan inspeksi mendadak (sidak) oleh Dinas Koperasi
Usaha Mikro Dan Perdagangan

Kota Pontianak terhadap pelaksanaan Perda Nomor 16 Tahun 2015 dalam pemungutan retribusi pasar Flamboyan sesuai dengan besaran tarif yang dikenakan ke pedagang.

4. Mengawasi para pedagang pasar Flamboyan dalam membayar retribusi pasar setiap harinya, jika masih ada keterlambatan atau menunggak pembayaran oleh pedagang, maka pemerintah Kota Pontianak melalui Dinas Koperasi Usaha Mikro Dan Perdagangan Kota Pontianak memberikan teguran secara lisan maupun tertulisberupa surat peringatan pertama, kedua dan ketiga maupun lisan, bahkan sanksi tegas berupa tidak diperpanjangnya surat izin perpanjangan tempat usaha (SPTU) bagi pedagang yang ingin memperpanjang tempat usahanya, baik los maupun kios. Sanksi berupa hukuman pidana atau berat tidak diberikan oleh Dinas Koperasi Usaha Mikro Dan Perdagangan 
Kota Pontianak kepada pedagang pasar Flamboyan, seperti pedagang yang menunggak masalah kerusakan pada fasilitas pembayaran retribusi pasar sarana pasar, yakni atap pasar yang Flamboyan, hal ini disebabkan mengalami kebocoran dibeberapa blok kondisi ekonomi pedagang los dan kios di pasar Flamboyan, pasar Flamboyan masih terutama di kios blok $\mathrm{F}$ dan Los blok golongan ekonomi menengah E, oleh Dinas Koperasi Usaha Mikro ke bawah yang bergantung Dan Perdagangan Kota Pontianak pada hasil dagangan mereka bersikap sangat lambat dan tidak sebagai mata pencaharian tanggap dalam merespon keluhan untuk mencukupi kebutuhan hidup mereka sehari-hari.

Salah satu bentuk sanksi administrasi yang diberikan oleh Dinas Koperasi Usaha Mikro Dan Perdagangan Kota Pontianak, sebagaimana tercantum pada gambar dibawah ini:

pedagang tersebut.

Hal ini dapat mengganggu aktivitas berjualan pedagang pasar Flamboyan juga dapat mengurangi pendapatan pedagang sebagai mata pencaharian mereka, sehingga pedagang pasar Flamboyan enggan untuk membayar retribusi pasar. Akibatnya, target penerimaan retribusi

Sikap pelaksana merupakan faktor yang penting dalam keberhasilan kinerja implementasi Peraturan Daerah Nomor 16 Tahun 2015, sikap petugas pemungut retribusi yang sering bertemu dengan pedagang dalam melakukan penarikan retribusi pasar, dinilai sangat ramah dan baik oleh pedagang, sehingga antara pertugas pemungut retribusi pasar dengan pedagang saling akrab. Namun, apabila ada keluhan dari pasar Flamboyan sebesar 100\% tak tercapai setiap harinya sebagai kontribusi bagi pendapatan asli daerah (PAD) Kota Pontianak.

Dalam mencapai target penerimaan retribusi pasar Flamboyan sebesar 100\% setiap tahunnya, Dinas Koperasi Usaha Mikro Dan Perdagangan Kota Pontianak perlu melakukan hal-hal sebagai berikut:

1. Melakukan evaluasi sekaligus pembinaaan terhadap kinerja 
petugas pemungut retribusi dalam pemungutan retribusi pasar agar optimalisasi penagihan retribusi pasar Flamboyan dapat meningkat.

2. Memberikan insentif bagi petugas pemungut retribusi berupa tambahan upah agar mampu melaksanakan tugas dengan penuh tanggung jawab dan memberikan kendaraan operasional kepada petugas pemungut retribusi pasar Flamboyan untuk kelancaran pelaksanaan pemungutan retribusi terhadap pedagang sehingga dapat meningkatkan penerimaan retribusi pasar.

3. Menegakkan sanksi yang tegas berupa hukuman berupa denda bagi keterlambatan pembayaran retribusi pasar, agar pedagang lebih disiplin dalam membayar retribusi pasarnya.

4. Melakukan pengawasan dengan berkeliling pasar setiap harinya oleh Dinas Koperasi Usaha Mikro Dan Perdagangan Kota Pontianak melalui seksi pembinaan dan sarana prasarana pasar tradisional bersama petugaspemungut retribusi, sehingga dapat menegur langsung ke pedagang yang tidak membayar retribusi pasar.

5. Meningkatkan pengawasan terhadap petugas pemungut retribusi dalam melaksanakan administrasi pendataan jumlah pedagang dan perhitungan serta pembukuan hasil pemungutan retribusi hingga pelaporan dan penyetoran hasil retribusi pasar ke kas Dinas Koperasi Usaha Mikro Dan Perdagangan Kota Pontianak dalam pemungutan target retribusi setiap harinya.

6. Melakukan pengawasan dengan melakukan sidak ke pasar Flamboyan oleh Dinas Koperasi Usaha Mikro Dan Perdagangan Kota Pontianak terhadap kinerja petugas pemungut retribusi pasar Flamboyan tentang bagaimana pelaksananan dilapangan dalam pemungutan retribusi terhadap pedagang pasar.

7. Meningkatkan kualitas sarana dan prasarana pasar Flamboyan dengan merespon secara cepat terhadap keluhan pedagang dalam memperbaiki sarana fasilitas pasar yang rusak agar segera diperbaiki. Hal ini dapat memberikan rasa 
kenyamanan pembeli dalam mikro Dan Perdagangan Kota berbelanja di pasar dalam Pontianak.

meningkatkan penerimaan retribusi pasar Flamboyan.

Komunikasi Antarorganisasi Dan Aktivitas Pelaksana Dalam Implementasi Kebijakan Retribusi Jasa Pelayanan Pasar

Dari hasil wawancara dan

observasi yang dilakukan oleh peneliti terhadap informan diatas dapat diambil kesimpulan bahwa berdasarkan komunikasi antarorganisasi dan aktivitas pelaksana, komunikasi yang terjalin antar aktor yang terlibat dalam proses implementasi kebijakan pemungutan retribusi pasar Flamboyan Kota Pontianak melibatkan Dinas Koperasi Usaha Mikro Dan Perdagangan Kota Pontianak, petugas pemungut retribusi dan pedagang. Proses komunikasi yang terjadi melalui sosialisasi berupa informasi mengenai pemberlakukan tarif retribusi baru sesuai dengan Perda Nomor 16 Tahun 2015. Setelah kebijakan pemungutan retribusi tersebut dilaksanakan maka akan dilakukan proses pengawasan terhadap pelaksanaan Perda Nomor 16 Tahun 2015 oleh Dinas Koperasi Usaha Koordinasi yang dilakukan antara petugas pemungut retribusi dengan pedagang pasar Flamboyan sudah cukup baik, hal ini terlihat dari petugas pemungut retribusi melakukan sosialisasi Peraturan Daerah Kota Pontianak Nomor 16 Tahun 2015 Tentang Retribusi Jasa Pelayanan Pasar kepada pedagang pasar Flamboyan dengan menggunakan cara dan bentuk penyampaian informasi tentang Perda Nomor 16 Tahun 2015 ke pedagang melalui surat edaran pemberitahuan ke seluruh pedagang pasar Flamboyan terkait dengan pemberlakuan tarif retribusi pasar yang baru oleh pemerintah Kota Pontianak.

Surat edaran pemberitahuan juga diberikan kepada pedagang yang pertama kali menempati tempat los/kios jualannya. Adanya sosialisasi tersebut, pedagang pasar Flamboyan merasa tidak keberatan atas kenaikan tarif retribusi yang baru sesuai dengan Perda Nomor 16 Tahun 2015. Apabila terdapat pedagang yang mengeluh terkait kenaikan tarif retribusi, maka menjadi tugas petugas pemungut 
retribusi pasar untuk menjelaskan ke pedagang pasar Flamboyan.

Namun kenyataannya, tidak semua pedagang di pasar Flamboyan memperoleh sosialisasi dari pelaksana kebijakan. Hal ini disebabkan kurang gencarnya sosialisasi tentang informasi pentingnya pembayaran retribusi pasar sesuai dengan Perda Nomor 16 Tahun 2015 yang dilakukan oleh Dinas Koperasi Usaha Mikro Dan Perdagangan Kota Pontianak kepada pedagang, hal ini dikarenakan petugas dalam memberikan sosialisasi tidak transparan dan informasi yang diberikan bukan yang baru dan sebatas hanya membagikan surat edaran pemberitahuan saja, hal ini menyebabkan banyak pedagang yang tidak mengetahui persis isi, tujuan dan manfaat dari Peraturan Daerah Nomor 16 Tahun 2015 tersebut, sehingga pedagang enggan untuk membayar retribusi pasar.

Selain dari pedagang tidak mengetahui isi dan tujuan Perda tersebut, juga kurangnya ketersediaan sarana informasi oleh pemerintah Kota Pontianak dalam mensosialisasikan Peraturan Daerah Kota pontianak Nomor 16 Tahun 2015. Sarana informasi yang tersedia saat ini sangat minim, hanya ada 1 (satu) pengeras suara dan 1 (satu) papan pengumuman,tempat kios dan los pedagang yang jaraknya jauh tidak terjangkau oleh petugas retribusi dalam menyampaikan informasi melalui pengeras suara dan surat edaran yang ditempelkan pada papan pengumuman, sehingga dapat mempengaruhi kesadaran dan kepatuhan dalam membayar retribusi pasar. Hal ini terlihat dari gambar dibawah ini:

Sehingga pemerintah Kota Pontianak melalui Dinas Koperasi Usaha Mikro Dan Perdagangan Kota Pontianak perlu membuat strategi untuk mendorong pedagang pasar Flamboyan untuk aktif membayar retribusi pasar Flamboyan agar target penerimaan pasar meningkat. selain petugas pemungut retribusi menarik retribusi pasar secara langsung mendatangi tenpat los/kios pedagang, juga memberikan kemudahan bagi pedagang untuk melakukan pembayaran melalui loket pembayaran yang disediakan sesuai dengan buku bukti pembayaran retribusi harian.oleh 
pedagang pasar Flamboyan, hal ini dapat dilihat dari gambar dibawah ini:

Dalam meningkatkan target penerimaan retribusi pasar Flamboyan sebagai kontribusi pendapatan asli daerah (PAD) Kota Pontianak diperlukan perbaikan-perbaikan dalam komunikasi dan koordinasi antar pelaksana kebijakan oleh Dinas Koperasi Usaha Mikro Dan Perdagangan Kota Pontianak dengan pedagang pasar Flamboyan, sebagai berikut:

1. Menyediakan sarana informasi yang lengkap dalam menunjang pelaksanaan sosialisasi yang dilakukan oleh Dinas Koperasi Usaha Mikro Dan Perdagangan Kota Pontianak berupa pengeras suara dan media gambar melalui televisi yang diletakkan disetiap blok los/kios yang ada di pasar Flamboyan serta disediakan CCTV selama 24 jam agar aktivitas pemungutan retribusi pasar ke pedagang terpantau setiap harinya. Selain itu, disediakan kotak saran dan kontak pengaduan oleh petugas pemungut retribusi agar keluhan pedagang dapat cepat direspon oleh Dinas Koperasi Usaha Mikro Dan
Perdagangan Kota Pontianak, hal ini dapat meningkatkan penerimaan retribusi pasar Flamboyan setiap harinya.

2. Dinas Koperasi Usaha Mikro Dan Perdagangan Kota Pontianak perlu mempublikasikan informasi yang diperbaharui secara berkala dan transparan tentang retribusi pasar, melalui sarana informasi yang disediakan oleh pemerintah Kota Pontianak, agar pedagang dapat mengetahui manfaat dan tujuan serta kegunaan dari hasil retribusi pasar yang dipungut oleh petugas pemungut retribusi setiap harinya, sehingga dapat menumbuhkan kesadaran dan kepatuhan pedagang dalam membayar retribusi pasar agar pencapaian target penerimaan retribusi pasar Flamboyan setiap harinya meningkat.

\section{SIMPULAN DAN REKOMENDASI}

\subsection{Simpulan}

Berdasarkan hasil penelitian dan temuan-temuan di lapangan mengenai implementasi Peraturan Daerah Nomor 16 Tahun 2015 tentang Retribusi Jasa Umum Pada Retribusi Pelayanan Pasar pada Pasar Flamboyan Kota Pontianak 
terkait dengan model implementasi kebijakan menurut Van Meter \& Van Horn maka penelitian ini dapat disimpulkan sebagai berikut:

1. Retribusi pelayanan pasar Flamboyan di Kota Pontianak merupakan salah satu sumber Pendapatan Asli Daerah (PAD). Kualitas pemungutan retribusi pelayanan pasar oleh petugas pemungut retribusi belum memuaskan, pedagang merasa bahwa apa yang dibayarkan sesuai kebijakan retribusi pasar, belum sesuai dengan pelayanan pasar yang diberikan oleh pemerintah Kota Pontianak, dalam hal ini respon terhadap keluhan pedagang mengenai kondisi sarana fasilitas pasar yang digunakan oleh pedagang, dari segi penanganannya lambat untuk ditindaklanjuti oleh Dinas Koperasi Usaha Mikro Dan Perdagangan Kota Pontianak, sikap petugas pemungut retribusi terhadap pedagang pasar Flamboyan kurang menunjukkan ketegasannya dalam memberikan pelayanan kepada pedagang dari segi penarikan retribusi pasar, sehingga kurangnya pengawasan yang dilakukan oleh Kasi Retribusi dan Registrasi Pengelolaan Pasar Tradisional terhadap kinerja petugas pemungut retribusi dalam pemungutan retribusi kepada pedagang, yang mengakibatkan penerimaan retribusi tidak maksimal, hal ini dapat mempengaruhi target penerimaan retribusi pasar Flamboyan.

2. Implementasi Peraturan Daerah Nomor 16 Tahun 2015 dapat dikatakan berhasil, apabila proses implementasinya sudah terkoordinasi dengan baik melalui komunikasi antara Dinas Koperasi Usaha Mikro Dan Perdagangan Kota Pontianak, petugas pemungut retribusi dan pedagang pasar Flamboyan dalam proses pemungutan retribusi pasar. Bentuk koordinasi yang dilakukan, yakni melalui sosialisasi mengenai implementasi kebijakan Perda Nomor 16 Tahun 2015 tentang pemberlakuan tarif retribusi baru. Namun, belum dilakukan secara maksimal disebabkan masih terdapat hambatan dalam pelaksanaannya, yakni kurang gencarnya pelaksana kebijakan oleh 
Dinas Koperasi Usaha Mikro Dan Perdagangan Kota Pontianak dalam memberikan informasi tentang isi dan tujuan serta manfaat dikeluarkannya Perda Nomor 16 Tahun 2015, hal ini dapat dilihat dari alat/sarana penyampaian sosialisasi oleh Dinas Koperasi Usaha Mikro Dan Perdagangan Kota Pontianak belum memadai. Akibatnya, tidak semua pedagang mendapatkan informasi dari sosialisasi tersebut, hanya melalui surat edaran pemberitahuan saja, dikarenakan tempat kios dan los pedagang yang jaraknya jauh tidak terjangkau oleh petugas retribusi, sehingga dapat mempengaruhi kesadaran dan kepatuhan dalam membayar retribusi pasar.

\subsection{Rekomendasi}

Berdasarkan kesimpulan di atas, maka saran yang peneliti antara lain sebagai berikut:

1. Perlu adanya sikap pelaksana, yakni petugas pemungut retribusi yang dapat diterima oleh masyarakat, khususnya pedagang pasar Flamboyan yang mengarah kepada kesanggupan membantu dan menyediakan pelayanan yang cepat, tepat serta tanggap terhadap keluhan pedagang pasar Flamboyan. Selain itu, memberikan sanksi yang tegas berupa denda kepada pedagang agar mereka mau disiplin membayar retribusi pasar. Pengawasan terhadap kinerja petugas pemungut retribusi perlu ditingkatkan dan memberikan tambahan insentif berupa upah tambahan kepada petugas pemungut retribusi serta kendaraan operasional untuk menunjang pelaksanaan pemungutan retribusi pasar Flamboyan terhadap pedagang, agar target penerimaan retribusi pasar Flamboyan lebih meningkat.

2. Melakukan pendekatan secara persuasif dengan selalu mengingatkan pedagang untuk membayar retribusi, yakni menggalakkan penyuluhan dan pembinaan dengan memberikan informasi tentang pentingnya pembayaran retribusi sesuai dengan Perda Nomor 16 Tahun 2015 yang transparan dan baru kepada pedagang melalui sarana informasi yang tersedia dan lengkap, agar pedagang dapat mengetahui 
kegunaan dan tujuan dari uang retribusi pasar yang dipungut oleh petugas retribusi pasar dalam meningkatkan kesadaran dan kepatuhan pedagang akan pentingnya retribusi dalam menunjang pendapatan asli daerah (PAD) Kota Pontianak.

\section{E. REFERENSI}

Agustinova, E. (2015). Memahami Metode Penelitian Kualitatif; Teori \& Praktik. Yogyakarta: Calpulis.

Anggara, S. (2014). Kebijakan Publik Pengantar. Bandung: Pustaka Setia.

Agustino, L. (2017). Dasar-dasar Kebijakan Publik Edisi Revisi. Bandung: Alfabeta.

Moleong, L. (2007). "Metodologi Penelitian Kualitatif Edisi Revisi”. Bandung: Remaja Rosdakarya.

Nawawi, H. (2001). Metode Penelitian Bidang Sosial. Yogyakarta: Gajah Mada University Press.

Pasolong, H. (2013). Metode Penelitian Administrasi Publik. Bandung: Alfabeta.

Ridha, S. M. ( 2015). Pengantar Kebijakan Publik. Jakarta: Calpulis.

Nugroho, R. (2006). Kebijakan Publik
Untuk Negara-Negara Berkembang

Jakarta: Elex Media Komputindo

Subarsono. (2005). Analisis Kebijakan Publik, Konsep, Teori dan Aplikasi. Yogyakarta: Pustaka Pelajar.

Sugiyono. (2006). Metode Penelitian Administrasi. Bandung: CV. Alfabeta

Sugiyono. (2012). Metode Penelitian Administrasi dilengkapi dengan metode $R$ \& $D$. Bandung: Alfabeta.

Silalahi, U. (2017). Metode Penelitian Sosial. Bandung: Refika Aditama.

Sugianto. (2008). ajak dan Retribusi Daerah. Jakarta: Grasindo.

Siahaan, M. P. (2015). Pajak daerah dan Retribusi Daerah. Jakarta: Raja Grafisindo Persada.

Tohirin. (2012). Metode Penelitian Kualitatif Dalam Pendidikan dan Bimbingan Konseling. Jakarta: Raja Grafindo Persada.

Tachjan. (2006). Implementasi Kebijakan Publik. Bandung: AIPI-Puslit KP2W Lemlit UNPAD.

Wahab, S. (20017). Analisis Kebijakan dari Formulasi ke penyusunan model-model Implementasi Kebijakan publik. Jakarta: Bumi Aksara Jakarta. 
Winarno, B.. (2014). Kebijakan Publik Teori, Proses dan Studi Kasus, Edisi

Revisi Terbaru. Yogyakarta: Center Academic Publishing Service.

Winarno, B. (2011). Kebijakan Publik (Teori, Proses dan Studi Kasus). Yogyakarta: Center Of Academic Publishing Service. 